Отже, раціональна організація самостійної роботи $є$ дієвим засобом для професійного становлення майбутнього гірничого інженера.

\title{
Література
}

1. Алексюк А. М. Педагогіка вищої освіти України: історія, теорія: [підручник] / А. М. Алексюк. - К. : Либідь, 1998. - 558 с. 2. Буряк В. К. Керування самостійною роботою студентів / Володимир Костянтинович Буряк // Вища школа. - 2011. - №45. - С. 48-52. 3. Гончаренко С. У. Український педагогічний словник / Семен Устинович Гончаренко. - К. : Либідь, 1997. - 376 с. 4. Закон України «Про вищу освіту»: науково-практичний коментар / МОН України; за заг. ред. В. Г. Креміня. К. : СДМ-Студіо, 2002. - 328 с. 5. Кайдалова Л. Г. Огранізація та контроль самостійної роботи студентів/ Л. Г. Кайдалова, Н. Шевченко // Проблеми освіти: науково-метод. зб. - К. : Наук.-мет. центр вищої освіти, 2004. - С. 136-142. 6. Наказ МОН України №450 від 07.08.2002. 7. Національна доктрина розвитку освіти України у XXI столітті // Освіта України. - 2001. - № 29 (18 липня). - С. 4. 8. Організація самостійної роботи студентів 3 педагогіки: [навч. посіб.] /за ред. В. І. Євдокимова. Х. : ХДПУ, 2000. - 160 с. 9. Пидкасистый П. И. Навыки самообразования важнейшая цель обучения / П. И. Пидкасистый, А. Е. Пасекунов // Вестник высшей школы. - 1984. - №4. - С. 31-32. 10. Про затвердження норм часу для планування i обліку навчальної роботи та переліків основних видів методичної, наукової і організаційної роботи педагогічних i науково-педагогічних працівників вищих навчальних закладів // Інформаційний збірник МОН України. - 2002. - № 22. - С. 311. 11. Положення про самостійну роботу студентів економічного факультету КНУ імені Тараса Шевченка // Вища школа. - 2007. - № 6. - С. 101-105. 12. Рубинштейн С. Л. Проблемы общей психологии /
С. Л. Рубинштейн. Педагогика, 1973. - 423 с.

УДК 355.23 : 355.233 .2 : 378 : 354.31 (477)

Сергій Іщценко

\section{ФОРМУВАННЯ ГОТОВНОСТІ МАЙБУТНІХ ОФЦЦЕРІВ ДО ВИХОВНОЇ РОБОТИ $З$ ОСОБОВИМ СКЛАДОМ У ВИЩОМУ НАВЧАЛЬНОМУ ЗАКЛАДІ}

Іщенко С. О. Формування готовності майбутніх офіцерів до виховної роботи 3 особовим складом у вищому навчальному закладі.

У статті розкрито сутність поняття «готовність майбутніх офіцерів до виховної роботи», основні складники готовності, визначено конкретні знання,вміння та навички, якими має володіти майбутній офіцер задля ефективного здійснення своєї професійної діяльності.

Ключові слова:готовність, майбутній офіцер, виховання, професійна діяльність.

Ищенко С. А. Формирование готовности будущих офицеров к воспитательной работе с личным составом в высшем учебном заведении.

В статье раскрыта суть понятия «готовность будущих офицеров к воспитательной работе», основные составляющие готовности, определены конкретные знания, умения и навыки, которыми должен обладать будущий офицер для эффективного осуществления своей профессиональной деятельности.

Ключевые слова:готовность, будущий офицер, воспитание, профессиональная деятельность.

Ischenko S. A. Training of the future officers for educational work with staff in higher education. 
This paper examines the essence of the concept of «readiness future officers to educational work», the basic ingredients ready, set specific knowledge and skills that should have future officers fo the effective performance of their professional activities.

Key words:readiness, future officer, education, professional activity.

На сучасному етапі реформування Збройних сил України актуалізована тенденція до вдосконалення професійної підготовки майбутніх офіцерів. Невід’ємним компонентом підтримки професійної підготовки військовослужбовцівє чітка система виховної роботи з особовим складом. В основу цієї системи традиційно було покладено ідеї служіння своїй Батьківщині, вірність та честь військовому кодексу офіцера, духовним традиціям армії.Головним носієм цієї ідеї є офіцер, який відповідає за навчання і виховання своїх підлеглих, формуючи у них почуття любові і поваги до Батьківщини. Видатний армійський вихователь М. Драгомиров писав: «Виховання солдатів повинно стояти вище освіти, виховання випустити не можна навіть у тому випадку, коли на підготовкуновобранців дається лише один день»[6].

Виховний процес $є$ одним із головних складників професійної підготовки майбутніх офіцерів. Професійна готовність курсантів здійснюється в межах чинної професійної підготовки офіцера-вихователя. Водночас відомо, щоорганізація виховного процесуможе мати емоційний компонент, тобто, офіцер-вихователь може керуватисясвоїмисимпатіями, асоціаціями, здогадками, почуттями і може забути про педагогічні методи виховання.Саме така особливість вихователя може критично відобразитися на побудові гуманних стосунків офіцера 3 курсантами та негативно вплинути на розв'язання поставлених завдань виховного процесу. Отже, постає проблема переглядутрадиційних методів вихованнямайбутніх офіцерівувищих навчальних закладах.

Питання формування готовності майбутніх офіцерів у процесі вишівської підготовки розглядається у працях С. Гаврилової, О. Ігумнової, В. Малого, В. Михаліна, О. Новікова, І. Утяшева та інших. Так, педагогічне забезпечення комплексної готовності розглядається С. Гавриловою як спеціально створені педагогічні умови, які сприяють формуванню знань, умінь, навичок майбутніх військових фахівців. До таких умов віднесено: визначення рівня підготовки курсантів; спеціальна підготовка офіцерів, які не мають педагогічної освіти, які є основними суб'єктами освітнього процесу; розроблення спеціальних технологій навчання військово-професійної підготовки.

Недостатньо розкритими $є$ питання, що стосуються сутності, складників, особливостей формування готовності майбутніх офіцерів до виховної роботи 3 особовим складом.

Мета статтіполягає у визначенні суті готовності майбутнього офіцера до виховної роботи з особовим складом,розкритті їі складників.

На думку С. Гаврилової, під комплексною готовністю майбутніх офіцерів до професійної діяльності слід розуміти створення інтегральної здатності особистості, яка відображає потребу до знань командного (управління військовими колективами), військово-інтегрованого (створення, обслуговування й управління складними технічними системами) і виховного (морально-психологічне забезпечення діяльності військового підрозділу) профілів. Кожний профіль передбачає сформованість компетенцій, що становлять базову основу для виконання доцільності дій в умовах як світового, так і військового часу. Командний, військово-інженерний i виховний профілі, які є складниками військової діяльності майбутнього офіцера, мають важливе значення в майбутній роботі молодого командира [1]. 
У своїй роботі автор розглянула механізми формування комплексної готовності: когнітивний (комплекс інтелектуальних якостей, формування яких забезпечує оптимізацію процесу саморозвитку і самоперетворення; творчий(передбачає розвиток уяви; інтуїцію, здатність і бажання до творчого пошуку); рефлексивний (забезпечує рефлексивну саморегуляцію); соціально-психологічний (сукупність психологічних упливів через соціум). До механізмів формування і розвитку комплексної готовності у курсантів до майбутньої професійної діяльності віднесено організаційні і психологопедагогічні умови, які забезпечують освітній процес майбутнього офіцера.

Автором виокремлено психолого-педагогічні умови формування комплексної готовності майбутнього офіцера до професійної діяльності, які передбачають: визначення рівня підготовки навчаючих; спеціальну підготовку майбутніх офіцерів, які не мають педагогічної освіти, але є основними суб'єктами освітнього процесу, розроблення спеціальних технологій освіти військово-професійної діяльності тощо.

Аналіз праці О. Новікова показав, що, на думку науковця, мета процесу формування готовності до професійної діяльності курсантів полягає у виробленні в курсантів сукупності спеціальних знань, умінь, навичок, якостей особистості офіцера, норм професійної поведінки, що забезпечує можливість успішного виконання обов'язків своєї служби.

Автором наведено приклад методики формування в курсантів готовності до професійної діяльності, яка реалізується у процесі використання сукупності форм: освітнього напрямку: лекцій, семінарів, практичних занять, групових вправ, навчальних занять у музеях, індивідуальних бесід, контрольних робіт, тактичних $\mathrm{i}$ тактико-спеціальних навчань; виховного напрямку: індивідуальна і групова бесіда, спільне зібрання навчального підрозділу, аналіз журналів, диспут, вікторина, «круглий стіл» 3 учасниками історичних подій, діячами науки, мистецтва, зустрічі 3 ветеранами війни, походи, екскурсії, проведення конференцій тощо.

Автор запропонував підхід, розроблений відповідно до трьох рівнів: 1-й - рівень освітньої взаємодії; 2-й- рівень професійно-середовищної взаємодії; 3-й - рівень внутрішньоособистісної рефлексії.

Перший рівень базується на взаємодії з курсантами, викладач формує у них погляди на життя, засоби мислення і дій. На другому рівні формується середовище курсанта й потреба бути особистістю, бути кращим. Середовище проживається людиною у формі змістовних структур. Таким середовищем $є$ навчальна група, факультет, ВНЗ, тобто це місце, де відбувається комунікація з іншими особистостями.

На третьому рівні внутрішньоособистісної рефлексії здійснюється адаптація курсантів до професійної діяльності. Рефлексивна функція виникає, коли $є$ труднощі і стоїть питання щодо розв'язання окресленої проблеми.

Саме коли особистість усуває свої труднощі, відбувається iï становлення як індивідуума та подальший розвиток у професійній діяльності [5].

У науковій праці І. Утяшев виокремлює морально-психологічну готовність як індивідуальну, динамічну характеристику стану офіцера, військового колективу, який зазнає впливу різних чинників, наприклад, військово-політичних, соціальних, економічних, які необхідні для реалізації морально-психологічного потенціалу під час розв'язання конкретних військових завдань.

Науковець розробив теоретичну модель процесу формування моральнопсихологічної готовності курсантів, яка містить логіко-методологічний, психологопедагогічний і технологічний блоки. Логіко-методологічний блок відображає мету, вихідні теоретичні чинники, які можуть впливати на формування морально- 
психологічної готовності курсантів до майбутньої професійної діяльності. У психолого-педагогічному блоці розкрито основні принципи формування моральнопсихологічної готовності майбутнього офіцера. Технологічний блок розкриває процесуальний аспект поетапної реалізації теоретичної моделі у військовій діяльності. Основу цієї моделі складає призначення випускників військового університету до подальшої діяльності у військах. Науковцем проаналізовано значення моральнопсихологічного чинника у професійній діяльності майбутнього офіцера. Модель повинна забезпечити підвищення мотивації курсантів та виробити в майбутніх офіцерів стійкість характеру, навчити використовувати нестандартні підходи та рішення для розв'язання поставлених завдань у сучасних умовах. На думку науковця, курсант повинен уміти працювати в команді, а командир має бути взірцем для майбутніх офіцерів [6].

На думку науковця В. Малого, готовність випускника військового інституту до професійної діяльності в якості спеціаліста автомобільної служби - це інтегральна професійно значуща якість особистості, яка складається з структурних компонентів: мотиваційного (спрямованість на виконання професійної діяльності на високому рівні), когнітивного (знання військової техніки в сукупності з високим рівнем теоретичної підготовки), операційного (вміння організовувати діяльність підлеглих), які вливають на здібності майбутнього офіцера керувати в подальшому військовим колективом, базуючись на сучасних технологіях і морально-вольовому компоненті (емоційновольова стабільність, адаптованість до екстремальних умов бойової обстановки).

Автор виокремлює основні компоненти готовності до професійної діяльності військовослужбовців на прикладі автомобільної служби. До них науковець відносить мотиваційний (спрямованість на виконання професійної діяльності на високому рівні, командні, організаторські, психолого-педагогічні навички роботи 3 підлеглими); когнітивний (знання військової техніки в сукупності з високим рівнем теоретичної підготовки, знання матеріальної частини наявності військової техніки і вміння нею користуватися); операційний: (вміння організовувати діяльність підлеглих, тобто це вміння, якими повинен володіти майбутній офіцер, базуючись на сучасних технологіях; морально-вольова: емоційно-вольова стабільність, адаптованість до екстремальнихумов бойової обстановки).

Науковцем розроблено модель готовності випускника військового університету допрофесійної діяльності на прикладі автомобільної служби. У ній використовуються психолого-педагогічні чинники, психологічний клімат у навчальній групі, формування емоційно-вольової та інтелектуальної сфери майбутнього офіцера, здатність до швидкого навчання, здатність швидко реагувати на нестандартні ситуації і приймати правильне рішення під час розв'язання ситуації, особистість інструктора (викладача) [3].

На думку О. Ігумнової, готовність - це комплексне новоутворення, що охоплює мотиваційно-ціннісну, когнітивну i діяльнісну сферу суб'єкта i виявляється в наявності особистісного смислу взаємодії в розумінні кінцевого результату загальної діяльності і бажання у спільному забезпеченні предметного і метапредметного знання i вміння, зокрема організаційного і регулятивного характеру, що реалізується в навчанні в малій групі [2].

В. Михалін готовність до професійної діяльності майбутніх офіцерів розуміє як інтегративну особистісну якість, що охоплює систему знань, умінь, навичок із фахових дисциплін, цілеспрямоване використання якої підвищує рівень військової практики. I тому автор акцентує увагу на мотиваційному, операційному i психофізіологічному складниках готовності, реалізація яких забезпечує результат 
становлення курсантів як особистості. На основі інтегративного підходу готовність передбачає мотиваційну готовність, професійну природність (психофізіологічний компонент), професійну підготовленість (операційний компонент). Проведена науковцем робота засвідчує те, що використання інтеграції змісту фахових дисциплін необхідне задля формування в курсантів готовності до професійної діяльності, професійного самовизначення, освіти й самоосвіти, професійного виховання i самовиховання. Водночас готовність до професійної діяльності $\epsilon$ регулятором діяльності, умов іiі ефективності, які впливають на формування професійних якостей військового фахівця [4]. На наш погляд, автор опосередковано торкається питань формування готовності майбутніх офіцерів до виховної роботи через виховання особистісних якостей. Тому в роботі не зазначено, як потрібно формувати готовність курсантів до виховної роботи з особовим складом.

Аналізуючи літературу [1; 2; 5], ми виокремили такі складники, що свідчать про сформованість готовності майбутнього офіцера до виховання військовослужбовців:

1. Науково-теоретична готовність: знання сутності й особливостей виховання майбутнього офіцера; форм і методів проведення виховної роботи в умовах ВНЗ, уміння відбирати та подавати курсантам необхідну інформацію.

2. Психологічна готовність: визначення мети, завдань, основних способів виховання курсантів; пізнавальний інтерес до вивчення та розуміння проблеми; здатність курсанта самому отримувати освіту; вміти критично ставитися до себе й коригувати свої дії у професійній діяльності у виховному процесі майбутніх офіцерів; формувати мотиваційну сферу курсантів.

3. Практична готовність: знання різноманітних методик проведення педагогічного діагностування, наявності вмінь i навичок роботи 3 інформаційним матеріалом; володіння педагогічними методиками організації і проведення виховної роботи.

Кожен майбутній офіцер повинен навчитися володіти конкретними уміннями, що уможливлюють ефективну організацію виховної роботи 3 персоналом. До таких умінь можна віднести:

- організаторські (уміння планувати виховну роботу; залучати курсантів до визначення та розроблення змісту цієї роботи; використовувати прийоми співробітництва й самоорганізації; контролювати й координувати виховний процес майбутніх офіцерів);

- цілепокладання (ураховувати індивідуальні особливості кожного майбутнього офіцера у виконанні завдань процесу виховної діяльності; формулювати цілі та завдання виховної роботи, виокремлювати основні завдання під час планування, підготовки і здійснення виховного процесу);

- оцінно-аналітичні (виокремлювати основні ознаки організованої роботи; вміти розрізняти спільні і відмінні риси споріднених і подібних явищ; факти, властивості, явища на основі аналізу організованої роботи; вміти проводити класифікацію й узагальнення результатів спостереження та дослідження; здійснювати оброблення інформації; ставити«педагогічний діагноз»);

- операційні, або практичні (спостерігати запедагогічними фактами, явищами, процесами; вміння визначати діагностувальні методи таметодики, адекватно ставитися до завдань; уміти аналізувати потрібну літературу; знаходити проблемні ситуації та вміти використовувати їх у виховній роботі 3 майбутніми офіцерами; фіксувати необхідну інформацію на електронному носії, для того щоб у подальшому аналізувати кожного курсанта;залучати майбутніх офіцерів до практичної діяльності, щоб передбачати вияв ними позитивних чи негативних якостей); 
- конструктивно-прогностичні (уміти складати методики і програми 3 виховної роботи 3 майбутніми офіцерами; визначати критерії та показники; формувати в курсантів здатність проводити самодіагностування; використовувати результати аналізу роботи майбутніх офіцерів у процесі планування подальшої роботи; складати діагностувальні матеріали до поставлених завдань виховного процесу; здійснювати дії практичного характеру на основі досліджень; визначати та застосовувати форми та методи виховного процесу до поставлених завдань майбутнього офіцера у виховному процесі).

У нашому розумінні готовність майбутніх офіцерів до виховної роботи 3 особовим складом становить особистісні інтегровані новоутворення в мисленні, свідомості, самосвідомості, якостях особистості майбутнього офіцера (виховні, інтелектуальні, психічні, фізичні, моральні та інші), які забезпечують самореалізацію особистості у професійній діяльності. Складниками готовності $є$ мотиви, потреби, знання та вміння виховної роботи, сформовані процеси самості (самовдосконалення, саморозвиток, самопізнання). Перспективним напрямком дослідження $є$ розроблення методики формування готовності майбутніх офіцерів до виховної роботи з особовим складом. У межах дослідження таку методику слід розробляти 3 позиції акмеологічного підходу, розглядаючи процеси самості рушійними силами здійснення виховної роботи у військах; 3 позиції компетентнісного підходу - професійні компетенції майбутніх офіцерів, 3-поміж яких знання і вміння виховної роботи $є$ значущими; з позиції особистісно-діяльнісного підходу - особистість офіцера, його права і обов'язки, професійні компетенції $є$ найвищими цінностями.

\section{Література}

1. Гаврилова С. Г. Формирование комплексной готовности будущих военных специалистов к профессиональной деятельности: автореф. дис. на соискание ученой степени канд.пед. наук: спец. 13.00 .08 «Теория и методика профессионального образования (педагогические науки)»/ Гаврилова С.Г..- Санкт-Петербург, 2011.24 с. 2. Игумнова О. В. Психолого-педагогический аспект понятия «готовность курсантов и слушателей ведомственного вуза к осуществлению группового взаимодействия»/О.В.Игумнова// Перспективы науки и образования. - 2014. № 1. - С. 186-188. 3. Малий В. И. Формирование готовности будущих офицеровРВСН к профессиональной деятельности в области автомобильной службы: автореф. дис. на соискание ученой степени канд.пед. наук : спец. 13.00 .08 «Теория и методика профессионального образования(педагогические науки)»/В. И. Малий. Шуя, 2010 - 24 с. 4. Михалин В. Н. Интеграция специальных дисциплин как средство формирования готовности к профессиональной деятельности курсантов образовательных учреждений МЧС России / В. Н. Михалин // Научный журнал КубГАУ. - № 87 (03). - 2013. - С. 1-10. 5. Новиков А. А. Формирование готовности к профессиональной деятельности у курсантов военных вузов : автореф. дис. на соискание ученой степени канд.пед. наук: спец. 13.00.08 «Теория и методика профессионального образования (педагогические науки)» / А. А. Новиков. - Москва, 2012. -24 с. 6. Офицерская памятка Драгомирова о воспитании солдат [Электронный pecypc]. - Режим доступа:http://www.slavyanin.ru/ index.php/cpvg/65-2010-02-22-09-0901. 7. Утяшев И. Р. Формирование морально-психологической готовности курсантов к будущей военно-пофессиональной деятельности в условиях модернизации войск: автореф. дис. на соискание ученой степени канд. пед. наук: спец. 13.00.08 «Теория и методика профессионального образования(педагогические науки)»/ И. Р. Утяшев. Казань, 2009. - 16 с. 